\title{
Legislation on the offence of rape in Icelandic criminal law
}

\author{
RAGNHEIĐUR BRAGADÓTTIR *
}

\section{Introduction}

For the past few decades sexual offences have been frequently discussed in Iceland. At first, the attention centred on how few guilty verdicts there were, as well as the lenient punishments, but in recent years attention has also turned to the concept of rape and how the crime of rape should be defined in the law. This discussion has taken place in the Icelandic Parliament (Althingi), in the courts' interpretations on the law, among scholars, and the public. The Icelandic General Penal Code (GPC) dates from 1940 and the provisions on sexual offences are in chapter XXII of the GPC. ${ }^{1}$ In the 80 years that have passed since the GPC came into force, chapter XXII has been revised in its entirety two times, in 1992 and 2007, and it is the only chapter in the GPC that has been subjected to such revision. In this article, section 2 will describe the general amendments made on the provisions on sexual offences in 1992, which included important amendments made on the provision on rape. Section 3 will then address the amendments made in 2007, when a very wide definition of the concept of rape was enacted. After that, section 4 will describe the amendments made on the provision on rape in 2018, when the word 'consent' was taken into the provision itself, but without any other major amendments on the provision. The current provision on rape in the GPC is made up of all these laws. This article will describe the academic discussion and societal views that were the precursor of these amendments. Finally, section 5 will evaluate the current provision and discuss whether further amendments are needed.

* $\quad$ Professor of Law, Faculty of Law, University of Iceland. I would like to thank the University of Iceland Research Fund for the grant that made it possible for me to write this article.

Email: rb@hi.is

1 The Icelandic General Penal Code (GPC) (no. 19/1940). 


\section{Revision in 1992: Two fundamental amendments}

\subsection{Precursor to the amendments}

In chapter XXII of the GPC there are various provisions that provide protection for people's sexual freedom. ${ }^{2}$ In sections 194-199 there are provisions on rape and other related offences. Originally, these provisions were based on the different means used for the offences, i.e., violence, threats, abuse, and deceit. Rape, according to section 194, was the most serious crime and was subject to the most severe punishment. Rape was defined as forcing a woman to have sexual intercourse using violence, by taking away her freedom, making her afraid for her life, health or wellbeing or that of those close to her, or depriving her freedom of action. If means other than those listed in section 194 were used to obtain intercourse, for example exploitation, abuse or deceit, the offence was not considered to be rape and was subject to much more lenient punishment. These provisions were left unchanged for half a century, from 1940 to 1992. Convictions for sexual offences were very few during this period and such offences were almost never discussed. However, Icelandic society changed considerably and knowledge on sexual offences slowly emerged. ${ }^{3}$ It had long since become time to revise the provisions, but the precursor to the revisions must be put into context with the development of women's struggles for gender equality in practice.

During the 1960s there was an increase in women who had received an education and entered the job market, which until then had mainly been occupied by men. At the beginning of the 1980s women became increasingly active in Iceland's public life and the Women's List ran for offices on the Reykjavík city council, as well as for the Parliament. The ideology of the women's movement was, among other things, that women's experiences and values were different from those of men. Women's voices had to be heard and they had to have an effect in society that was equal to men. ${ }^{4}$ This was a prerequisite for a discussion on protection against sexual violence. At the same time, a women's shelter was founded in Reykjavík. In spring 1984 the offence of rape and the rights of the victim were much discussed in society when a controversial custody decision in a rape case was met with a harsh reaction from the feminist movement,

2 It is customary to categorize these provisions into four groups: 1) Rape and other offences against people's sexual freedom, 2) Sexual offences against children, 3) Prostitution and 4) Indecent exposure and pornography.

3 Bragadóttir, Kynferðisbrot [Sexual offences] (Lagastofnun Háskóla Íslands 2006) p. 90.

4 Styrkársdóttir, From social movement to political party: the new women's movement in Iceland. The New Women's Movement - Feminism and Political Power in Europe and the USA (1986) pp. 140-157, at 141 and 150. 
as it demanded a revision on the law and its implementation. ${ }^{5}$ Subsequently, a committee of specialists was established, which worked for a few years on researching how the law dealt with rape and how rape cases were handled in the criminal justice system. ${ }^{6}$ The result of this work was that the Act on Criminal Procedure was amended and the position of the victim was strengthened, ${ }^{7}$ an emergency room for victims was established, the education and training of police and health care workers in this field were improved, and Act no. 40/1992, a new chapter on sexual offences, was added to the GPC. ${ }^{8}$ One of the main reasons for the revision of the chapter on sexual offences was therefore the influence of the feminist movement, which demanded that the provisions on sexual offences should reflect changed attitudes in this field, as well as new information available on the handling of these cases in the criminal justice system and the consequences that the offences have on the victims. ${ }^{9}$

\subsection{Non-gender-related provisions - sexual intercourse and other sexual relations}

With the law from 1992 two important amendments were made on all the provisions on sexual offences. First, all of the chapter's provisions were changed to non-genderrelated provisions. Before the law was amended, they had been gender-related, i.e., only women were protected by the law and could be victims and only men could be perpetrators. As biological gender is no longer decisive for the law, now both men and women can be perpetrators and victims. ${ }^{10}$

5 Bragadóttir, Nauðgun og önnur brot gegn kynfrelsi fólks [Rape and Other Offences against People’s Sexual Freedom] (Codex 2018) pp. 36-37. The case in question is $H$ 1984, 678 (91/1984). A man was accused of raping a girl and having attempted to rape another girl that same night. He confessed to the charges, but the demand for him to be held in custody was rejected in the district court, as the court deemed that the conditions for investigative interests and likely punishment for the offences were not fulfilled. In the Supreme Court, the majority agreed to the demand for custody, with rather weak arguments. Many thought that the Court had given in to the pressure and anger that had come up in society following the district court's rejection.

6 The committee delivered a report on the provisions on rape in the GPC, the criminal procedure in rape cases and the victims' experiences, and put forth suggestions for amendments, see Skýrsla nauðgunarmálanefndar [The Report of the Committee on Rape] 1989.

7 Act no. 36/1999, see Bragadóttir and Kristjánsson, Islandsk kronik 1994-1999 [Icelandic chronicle 1994-1999] in 87 Nordisk Tidsskrift for Kriminalvidenskab (2000) pp. 333-344, at 339340 .

8 Bragadóttir, Islandsk kronik 1984-1993 [Icelandic chronicle 1984-1993] in 81 Nordisk Tidsskrift for Kriminalvidenskab (1994) pp. 384-424, at 403-405.

$9 \quad$ Bragadóttir 2018 p. 37.

10 For a long time, there were no examples in Icelandic judgements of a woman being guilty of rape. The first known judgement on that is a judgement from a district court in 2007 (S-902/2007), where a few female friends went together to a summer house and one of them licked another one's genitals as she was passed out from drinking. In a few judgements in the Supreme Court, men have been found guilty of raping other men, for example H 23. May 2013 (93/2013), H 30. January 2014 (439/2013) and H 26. November 2015 (152/2015). 
Secondly, so-called 'other sexual relations' were equated with sexual intercourse so that the offence is now considered to be rape whether or not it is executed with sexual intercourse or other sexual relations. Before the amendments in 1992, an act was not rape unless there was sexual intercourse, and other sexual relations were subject to less severe punishment, according to a special provision thereon. The term 'intercourse' was, and still is, defined as traditional sexual intercourse between a man and a woman. Before the amendments in 1992 an offence was considered to be attempted rape until the perpetrator had penetrated a woman's vagina with his penis and movements of intercourse had begun. ${ }^{11}$ This changed in 1992 because according to the commentary handed in with bill of law no. 40/1992 the intercourse is fully completed when a perpetrator penetrates the vagina, whether it be fully or partially, and there does not need to have been any ejaculation and the hymen does not need to have ruptured, if that is applicable. ${ }^{12}$ The need to define fully completed sexual intercourse is, however, not as important as before, as other sexual relations are now equated with sexual intercourse. There is therefore no difference between rape committed through intercourse or other sexual relations. But what does 'other sexual relations' mean?

In the commentary from 1992, the concept 'other sexual relations' is explained rather narrowly as sexual exploitation which is equal to traditional intercourse or has the same relevance. These are actions that give the perpetrator sexual satisfaction or are generally used for that purpose. ${ }^{13}$ Here, comes up the question on what kind of activity this could be. There are no further explanations in the commentary. Jónatan Pórmundsson mentions sexual relations that are directed at other parts of the body than genitals or performed with tools. ${ }^{14}$ The commentary with the bill enacted as Act no. 61/2007 further elaborates on the definition of the concept of other sexual relations. There it says that by looking at the references made in the commentary for the bill of law no. 40/1992 to the contemporary Norwegian provision, judgements, and academics' explanations, including Danish and Norwegian, on corresponding concepts in Danish (anden kønslig omgæengelse) and Norwegian (seksuell omgang, which actually also includes intercourse) laws, we can come to the conclusion that the concept 'other sexual relations' in the Icelandic GPC includes oral and anal sex. ${ }^{15}$ The same applies to the act of penetrating the vagina or anus with objects or fingers, licking or sucking genitals, as well as a perpetrator's act of making a victim masturbate and movements of intercourse between a victim's thighs, bottom or stomach. ${ }^{16}$ In judgements on rape and other offences against people's sexual freedom it is more common that the act is executed through intercourse than through other

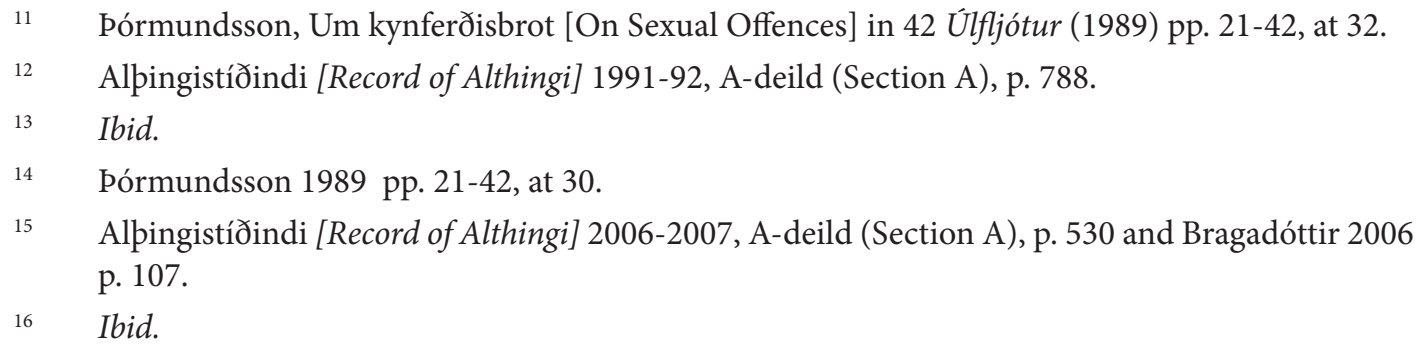


sexual relations. Based on judgements, it can be deduced that other sexual relations are commonly oral sex or anal sex. ${ }^{17}$

\subsection{The provisions on rape and other offences against people's sexual freedom after the amendments in 1992}

The provisions on rape and other offences against people's sexual freedom were kept in sections 194-199 of the GPC. As before, different means of obtaining sexual intercourse or other sexual relations separated the offences and the severity of the offences depended on the means used. However, the provisions were amended so that the difference between them was made clearer and the wording more modern. ${ }^{18}$ The most important provision, and the one that was most tried before the courts, was section 194 on rape. The means used for rape were violence or threats thereof. It was the most serious of the offences and subject to the most severe punishment, imprisonment of at least one year and not exceeding sixteen years. Offences against provisions of the chapter other than section 194 did not count as rape in the legal meaning of the concept. If the threats were of anything other than violence, the offence would fall under section 195 of the GPC on other forms of unlawful sexual coercion. Exploitation was the means mentioned in section 196, abuse in sections 197-198, and in section 199 the means were deceit. Offences against sections 195-199 were subject to much lighter punishment than rape according to section 194, i.e., imprisonment not exceeding three, four, or six years. Additionally, these provisions were not tried as much in courts as the provision in section 194, although during the last years of the $20^{\text {th }}$ century the usage increased of the provision in section 196, on offences where the victim's mental handicap, sleep or inebriation was taken advantage of to have intercourse or other sexual relations with the victim. ${ }^{19}$ This practice of the courts confirms that in the Act from 1992, the means used to violate people's sexual freedom were still very important.

\section{Revision in 2007: Comprehensive provision on rape}

\subsection{Background}

During the years after Act no. 40/1992 came into force, common knowledge on sexual offences, their characteristics and consequences increased rapidly. Discussion in society on these offences became much more open and it became more common

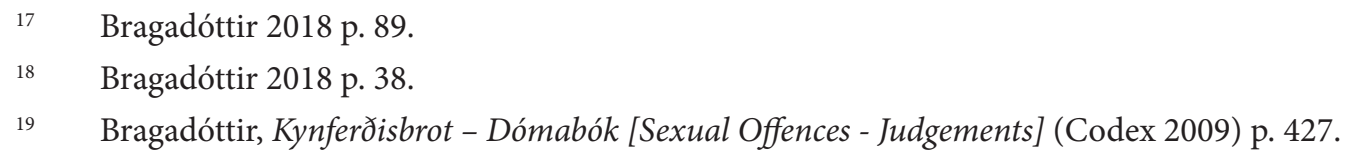


for victims of the offences to step forward and describe their experiences. ${ }^{20}$ There was no doubt anymore how common and harmful these offences were, both to those who had to endure them and to society as a whole. Even though convictions for certain types of sexual offences had become more frequent, it was clear that many of the offences never came into the open. The ratio of reports in these offences was increasing in Iceland but there were very few guilty verdicts. As an example, a research report revealed that in 2008 there were 88 reports on rape to the police, ${ }^{21}$ but only six convictions for rape in the Supreme Court. ${ }^{22}$ Even though the GPC's provisions on sexual offences had been revised in 1992, there was growing criticism on some of the provisions. They were considered to be insufficient in providing the victims of the offences the protection they needed, and some thought that there were possibly still old and outdated attitudes towards women hidden in the provisions themselves. The definition of the concept of rape in the GPC, i.e., the condition of violence or threats thereof, was not in accordance with people's general ideas on what rape entailed. ${ }^{23}$ Additionally, the sentences imposed by the courts were thought to be too lenient, especially when children were the victims of the offences. ${ }^{24}$

In addition to the aforementioned criticism on the GPC's provisions on sexual offences and their application, there was increased criticism on the large difference made between sexual offences according to the means used for the offence. ${ }^{25}$ The reason was, among other things, that the essence of a sexual offence was now understood as the violation of the victim's right to self-determination in sex, the victim's freedom and privacy. The means used then became less important.

All of this led to the decision in 2005 to revise the provisions in the chapter on sexual offences. The Minister of Justice asked me to write a draft bill for amendments on the provisions, including the provisions on rape and other offences against people's

20 See, for example: Baugalín, Launhelgi lyganna (Mál og menning 2000), Gerður Kristný and Ásdísardóttir, Myndin af pabba - saga Thelmu (Forlagið 2005), Jónsson and Elíson, Breiðavíkurdrengur - brotasaga Páls Elísonar (Mál og Menning 2007), Hirst, Ekki líta undan Saga Guðrúnar Ebbu dóttur Ólafs Skúlasonar biskups (JPV 2011), Gísladóttir, Hljóðin í nóttinni - Minningasaga (Veröld 2014) and Árnadóttir, Mörk - saga mömmu (JPV 2015).

$21 \quad$ Antonsdóttir and Gunnlaugsdóttir, Tilkynntar nauðganir til lögreglu á árunum 2008 og 2009: Um afbrotið nauðgun, sakborning, brotapola og málsmeðferð [Rape reported to the police in 2008 and 2009: On rape, perpetrators, victims and proceedings] (2013) p. 11.

$22 \quad$ Bragadóttir 2009 pp. 398-399.

23 Bragadóttir 2018 p. 42.

24 Bragadóttir, Nye lovændringer og strafudmåling for seksualforbrydelser mod børn [Sexual offences against children: Revision of the GPC and sentencing] in Kriminalistiske pejlinger Festskrift til Flemming Balvig (Jurist- og Økonomforbundets Forlag 2015), pp. 27-42.

25 This differentiation is criticised in my works: Slægð eða ofbeldi? Um ákvæði 196. gr. hgl. [Cunning or Violence? On section 196 of the GPC], Rannsóknir í félagsvísindum VI (Félagsvísindastofnun Háskóla Îslands 2005) pp. 271-300 and Er pörfá sérákvæði um aðra ólögmæta kynferðisnauðung? [Is a Special Provision on Other Forms of Unlawful Sexual Coercion Necessary?], Rannsóknir í félagsvísindum VII (Félagsvísindastofnun Háskóla Íslands 2006) pp. 221-236. 
sexual freedom, sections 194-199 of the GPC. Many sources were consulted when writing the bill. First, there was my research on the provisions in the chapter on sexual offences in the GPC, both on the law itself and its implementation. This research included a review of the Supreme Court's judgements in this field for the past decades, their dissection and comparison. Secondly, the law on sexual offences in other countries was researched, especially Danish, Finish, Norwegian and Swedish, German, English, and Irish law, and special attention was given to the amendments that had then recently been made on the law in some of these countries. Thirdly, sociological and criminological research and data concerning the extent and nature of these offences in Icelandic society were taken into account. Finally, I familiarised myself with the experience of many NGOs' who work with victims of these offences. ${ }^{26}$ In the introduction to the commentary handed in with the bill, I stated that I sought to have the amendments proposed fit to the system that already existed in the GPC. Emphasis was also put on having the provisions themselves simple and clear, but their explanations in the commentary extensive. A particularly important goal was to increase the legal protection of women and children and to make the provisions more modern. Another goal was to secure, as much as is possible with the law, that the privacy, self-determination, sexual freedom, and the freedom of action of all individuals would be respected. ${ }^{27}$ The bill was enacted in 2007, with a few minor changes. ${ }^{28}$ It can be argued that the amendments were based on both academic research and the views of the grassroots movements on these offences.

\subsection{A new provision on rape}

The most important amendments concerning rape and other offences against people's sexual freedom were a new definition of the concept of rape, as well as provisions on objective and subjective considerations to be taken into account in sentencing. The provision on rape was made more extensive and offences against people's sexual freedom were no longer differentiated according to the means used for the offence. In the commentary submitted with Act no. 61/2007, I discussed in detail how to make the provision on rape more extensive. There were two possible options. One was to make it more extensive by including more means than violence and threats thereof in the provision and thus try to cover all occasions where intercourse and other sexual relations happen without consent. Another option was to define rape in the provision itself as intercourse or other sexual relations without consent. In the commentary, both options were discussed before a conclusion was drawn on which option to choose. ${ }^{29}$

First it was discussed whether rape should be defined based on the concept of consent. At that time, discussion in society, especially among feminists, centred on

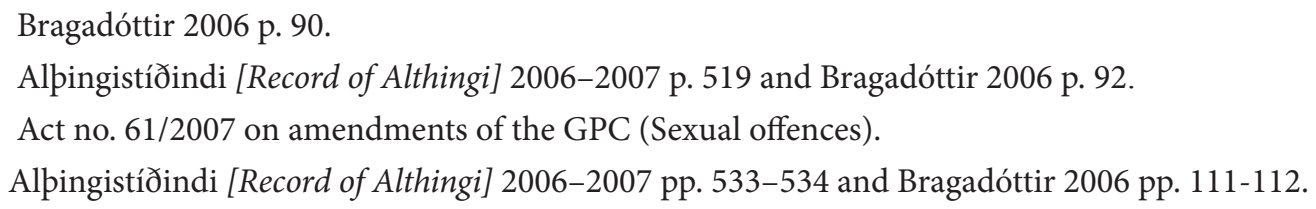


the need to emphasise the victim's consent or the lack thereof, and that the concept of rape had to be defined as based on consent. ${ }^{30}$ That would prevent cases from being dependent on what the victim did or did not do, and shift the focus to the unlawful and punishable act performed by the perpetrator. The definition would then be similar to the provision on rape in English and Irish law. ${ }^{31}$ Rape would then be considered as sexual intercourse or other sexual relations against the will of the victim where the perpetrator knew that the victim had not consented. This definition was rejected in the 2007 bill. ${ }^{32}$ The arguments for the rejection included that a concept of rape defined as sexual intercourse or other sexual relations performed without the victim's consent, was too unclear. Defining rape by (lack of) consent also called for a detailed explanation on how to define consent. Thus it had to be clear whether consent was obtained legally and not by unlawful means, for example violence, threats, or unlawful coercion, and that the victim was capable of giving consent. It was considered debatable whether a definition like this would really solve the problem, because proving a subjective concept like consent or the lack thereof would be very difficult. That type of proof would probably also focus on behaviour of the victim, i.e., what the victim said or indicated, instead of the perpetrator's behaviour. This was not desirable. Additionally, it was argued that the lack of consent was included in the concept of rape, because it was the lack of consent that made the act rape and therefore punishable. ${ }^{33}$ The conclusion in 2007 was therefore not to define the concept of rape only by lack of consent to the intercourse or other sexual relations, but to make the existing provision more extensive so that more means than before would be punishable. ${ }^{34}$ In order to describe the offence of rape clearly, and thereby to fulfil the requirement for the clarity of criminal provisions, means were mentioned which were supposed to cover the incidents where intercourse or other sexual relations occurred without the victim's consent. ${ }^{35}$ In the new provision from 2007, the concept of rape was mentioned in the provision itself for the first time, and the provision included a description of what the offence of rape contained. After the amendments done on the provision on rape with Act no. 61/2007, the new provision looked like this:

30

1 In English law (Sexual Offences Act 2003) the elements of rape are that the perpetrator intentionally penetrates the vagina, anus, or mouth of the victim with his penis, the victim does not consent to the penetration, and the perpetrator does not reasonably believe that the victim consents. Here, consent is defined as a person freely agreeing by choice and having the freedom and capacity to make that choice. According to Irish law (the Criminal Law (Rape) (Amendment) Act 1990) a man commits rape if (a) he has unlawful sexual intercourse with a woman who at the time of the intercourse does not consent to it, and (b) at that time he knows that she does not consent to the intercourse or he is reckless as to whether she does or does not consent to it.
Alpingistíðindi [Record of Althingi] 2006-2007 pp. 533-534 and Bragadóttir 2006 pp. 111-112.

Bragadóttir 2006 p. 76.

Alpingistíðindi [Record of Althingi] 2006-2007 p. 534 and Bragadóttir 2006 pp. 111-112.

Alpingsitíðindi [Record of Althingi] 2006-2007 p. 552 and Bragadóttir 2006 p. 136. 
'Section 194 subsection 1: Any person who has sexual intercourse or other sexual relations with a person by means of using violence, threats or other unlawful coercion shall be guilty of rape and shall be imprisoned for a minimum of 1 year and a maximum of 16 years. 'Violence' here refers to the deprivation of independence by means of confinement, drugs or other comparable means.

Section 194 subsection 2: Exploiting a person's psychiatric disorder or other mental handicap, or the fact that, for other reasons, he or she is not in a condition to be able to resist the action or to understand its significance, in order to have sexual intercourse or other sexual relations with him or her, shall also be considered as rape, and shall result in the same punishment as specified in the first paragraph of this Article. ${ }^{36}$

With this provision the concept of rape was made much more extensive than it was before and there were four changes that caused this.

First, the element of force was removed from the provision on rape. Before the amendments in 2007, force was a part of the wording of the provision, which said that it was punishable to force a person to have sexual intercourse or other sexual relations. This wording made clear the assumption that rape included force. But the problem with this wording was that it could lead to too much emphasis on proving the victim's reaction in rape cases, for example whether the victim fought back against the perpetrator, and with this the perpetrator's actions lost their importance. In a Supreme Court judgement from 2004 this was very apparent, where the result was based on whether the use of force was proven. ${ }^{37}$

In this case, M, 22 years old, was accused of offences against sections 194 and 196 of the GPC for forcing his 14-year-old cousin, Y, to other sexual relations than intercourse by pressing her head up against his penis, forcing his penis into her mouth and holding her head tightly while he moved his penis front and back and having to some degree used the fact that she was not able to resist the action because of inebriation. The Supreme Court said it was obvious that the accused had exploited his age and position as Y's older relative and confidant, as well as Y's inebriation. Nevertheless, the conclusion was that $\mathrm{M}$ was acquitted. It was not deemed proven beyond reasonable doubt that $\mathrm{Y}$ had been so inebriated that she could not have resisted the act. It was also deemed unclear whether she had been forced and the accused had to be given the benefit of the doubt.

It was very unfortunate to have verdicts depend on what the victim did or did not do, just as happened in this case, instead of being mainly about the unlawful and punishable act of the perpetrator. That was the reason why force was removed from the provision on rape in 2007 and more emphasis being put on the causal connection between violence, threats, or other forms of unlawful coercion, and the intercourse

\footnotetext{
36 Official translation obtained from: https://www.government.is/library/Files/General_Penal_ Code_sept.-2015.pdf

$37 \quad$ H 2004, 1111 (416/2003).
} 
or the sexual relations the perpetrator obtains. After the amendments in 2007, the emphasis was therefore on the unlawful act of the perpetrator, which is the core of the crime and what the proof is supposed to focus on, not on whether the victim was forced and if or how the victim defended her/himself against the attack. If it was proven that the perpetrator used violence, threats, or other forms of unlawful coercion to have intercourse, it had to be assumed that the victim was forced to have intercourse, because otherwise these means would not have been necessary to obtain it. Additionally, it was assumed that the new wording reflected better how women react to attacks than the older wording of section 194. With the amendments on the provision on rape in 2018 this definition has become part of the definition of consent. ${ }^{38}$

Secondly, the provision in section 194 on rape was made more extensive so that other forms of unlawful sexual coercion now became defined as rape. ${ }^{39}$ This meant that all threats, not only threats of violence, were now included in section 194. In 1940 the means, according to section 194, were to make the woman fearful of her own life, health, or wellbeing or that of those close to her. In 1992 the provision was amended, and the means were made more extensive in two ways. ${ }^{40}$ Thus the provision reached all punishable threats of violence, but not other threats. Additionally, it was no longer required that a threat should invoke fear of life, health, or wellbeing. In the commentary, it said that threats of violence were generally so serious in nature that it was unnecessary to keep this requirement. ${ }^{41}$ If threats of something other than violence had been used to obtain sexual intercourse, section 195 on other unlawful sexual coercion was applicable to the offence. After Act no. 61/2007 came into force, all threats were included in section 194 subsection 1 on rape and it was therefore no longer required that a threat included violence. The nature of the threat could be various, and the provision's content was therefore much more extensive than before. The threat had to be essential to the perpetrator obtaining sexual intercourse or other sexual relations which he/she would otherwise not have obtained, i.e., there had to be a causal connection between the threat and the sexual intercourse. The less weight that a threat carries, the less likely it is to have led to intercourse. ${ }^{42}$

Thirdly, the exploitation of mentally ill and disabled people and those who cannot defend themselves against the offence because of inability was defined as rape with the Act from 2007.33 These were offences that were previously considered to be sexual exploitation according to section 196, which was subject to much more lenient punishment than rape according to section 194, i.e., imprisonment not exceeding six years. The first decades after the GPC from 1940 came into force, the contemporary

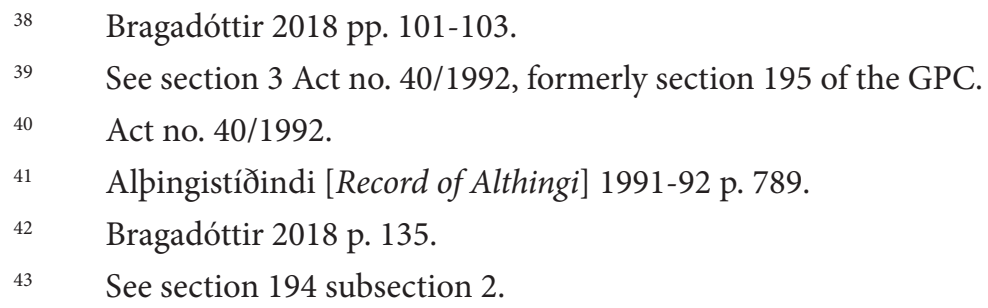


section 196 of the GPC was almost never applied, but after the turn of the millennium there was a slow increase in cases. ${ }^{44}$ It did, however, catch my attention that the provision, which was supposed to specifically protect the mentally ill and disabled, seemed to have the opposite effect, i.e., they actually had less legal protection than those who were completely healthy. Supporting this statement was the fact that there seemed to be no cases in the Supreme Court on rape according to section 194 of a mentally ill or disabled victim. Such offences seemed to always fall under section 196, which were subject to much less severe punishment than rape according to section 194. The arguments for this were probably that no violence had been used. But the counterargument was that the perpetrator often does not need to use violence, because those who are mentally ill or disabled will give in without it. Threatening looks or orders can be enough for the perpetrator to get his/her way and such behaviour often includes threats of violence which should have been sufficient for a guilty verdict according to section 194. It would also be difficult to argue why sexual intercourse obtained with violence is a more serious offence than intercourse with an unconscious person, who for example is sleeping in his/her own bed and not expecting anything bad to happen, or a disabled person, who is defenceless and cannot save him/herself. ${ }^{45}$

In the commentary with the bill of law no. 61/2007 it was pointed out that this emphasis on violence as means was outdated and did not reflect the reality that victims of the offences experienced. The most serious aspect of the offences in sections 194-199 is that they violate people's sexual freedom, their freedom of action, privacy, and self-determination in sex. It could therefore be argued that it was not right to differentiate between offences against people's sexual freedom based on which means were used to carry out the offences. Sexual offences against those who are mentally ill, disabled, sleeping, or unconscious are all just as serious as rape according to section 194 and the law had to reflect this fact. ${ }^{46}$ With the Act from 2007 the legal status of this group therefore greatly improved.

Fourthly, the provision in section 199 of the GPC on punishment where deceit was the means used to obtain sexual intercourse was abolished. This provision detailed criminal liability in three types of situations where the perpetrator abused

44 Bragadóttir 2009 p. 427. The first judgements in the Supreme Court where the provision was applied date from 1986-89. The accused were found guilty of sexual intercourse with disabled women, i.e., H 1986, 682 (21/1986), H 1987, 1179 (90/1987), H 1989, 343 (201/1988) and H 1989, 352 (227/1988). It was first in 1991 that a perpetrator was found guilty in the Supreme Court for a sexual offence against a woman who could not resist his actions because she was passed out from drinking, i.e., H 1991, 802 (46/1991).

$45 \quad$ Bragadóttir 2006 p. 101.

46 Pingskjal [Document of Althingi] 20 - 20. mál, 133. löggjafarping 2006-2007 pp. 11-12 and Bragadóttir 2006 p. 101. 
the victim's misunderstanding of the situation to have intercourse. ${ }^{47}$ This provision was very rarely tried by the courts, and only used twice in the Supreme Court's judgements for over more than 60 years, from 1940 to $2006 .^{48}$ The arguments for abolishing the provision were that it could most likely be applicable if the victim of an offence was asleep, had a mental illness, or a disability. If the victim was in such a condition, this would be a more serious crime than described in section 199, i.e., exploitation, and the conditions for criminal liability in section 194 subsection 2 on rape were fulfilled. There was therefore no need for this provision anymore.

With this new definition from 2007 the concept of rape became very extensive. The purpose was that the new provision on rape should cover those incidents where sexual intercourse or other sexual relations were had against the victim's will, i.e., without the victim's consent, as it was the essence of rape that there was no consent to the intercourse, even though this was not explicitly stated in the provision itself. With the new provision, emphasis was laid on the fact that sexual intercourse was had with a victim without consent and it was thereby a violation of the victim's self-determination and sexual freedom. ${ }^{49}$ The main models for the provision were new amendments on the Norwegian and Swedish criminal codes. ${ }^{50}$

\subsection{Violence, threats and other forms of unlawful coercion}

Violence, according to section 194, is a very broad concept. There are no requirements on the nature of the violence. An attack does not have to lead to physical injuries, loss of health, or any consequences other than the intercourse which was the objective of the violence, as intercourse is the most important part of the offence. There are also no requirements regarding the victim having to actively fight back. ${ }^{51}$ It was presumed that the provision on rape in section 194 would always be used along with the provisions on the sexual abuse of children when an adult has intercourse or other sexual relations with a child, as this is the exploitation of the superior position the adult has over the child. In recent years, this understanding has been recognized by the courts. ${ }^{52}$

47 These incidences were: The victim thought, wrongly, that the sexual intercourse were performed within a marriage or a common-law marriage, the victim thought he/she was having sexual intercourse with someone other than he/she really was, for example because of darkness, or sexual intercourse was had because he/she had been deceived that it was a medical or otherwise scientific treatment.

48 These are H 1943, 167 (52/1942) and H 1996, 3030 (289/1996).

49 Alpingistíðindi [Record of Althingi] 2006-2007 pp. 533-534 and Bragadóttir 2018 pp. 101-103.

50 Chapter 26: On sexual offences, in the Norwegian Criminal Code (Straffeloven, Lov-2005-0520-28) from 2005 with amendments. Chapter 6: On sexual offences, in the Swedish Criminal Code (Brottsbalken 1962:700), as amended in 2005.

51 Bragadóttir 2018 p. 124.

52 H 1. October 2015 (170/2015), H 8. June 2017 (733/2016), L 19. October 2018 (229/2018) and L 5. April 2019 (368/2018). 
There are no requirements for threats used and all threats are included in the provision. The threat can include legal actions, such as threatening to file a charge for actual theft, or illegal, such as threats of violence, destruction of property, or defamation..$^{53}$ Threats can therefore concern anything and must only have the effect that the victim gives in. The threats most often tried by the courts are threats of violence. This includes threats of violence performed immediately or later. Threats of publishing nude or sexual photos on the internet without consent if the victim does not do what the perpetrator wants is a new reality and can be categorized as a threat according to section 194 and be rape or attempted rape. ${ }^{54}$ This has come up in Supreme Court judgements, for example in a judgement from 2016. ${ }^{55}$

In this case, $\mathrm{X}$ was accused of attempted rape by threatening to publicly spread sexual conversations had with B, a 15-year-old boy, and a picture of B's genitals if B would not have intercourse with him before 23 oclock that same night. He put an enormous amount of pressure on B in his communication with him online and did not stop pressuring him until just before 23 oclock when B's mother became aware of what was happening and took over the communication. The district court deemed it proven that X wanted to obtain sexual intercourse this way and that X's actions had shown that intention beyond any doubt. $\mathrm{X}$ was therefore found guilty of attempted rape, i.e., an offence against section 194 subsection 1, cf. section 20 subsection 1 of the GPC. The majority in the Supreme Court (three of five) confirmed the district court's judgement that it was proven that $\mathrm{X}$ had threatened $\mathrm{B}$, that $\mathrm{B}$ had taken the threats seriously, and that $\mathrm{X}$ had used the threats to try to force $\mathrm{B}$ to have sexual intercourse with him. Thus, $\mathrm{X}$ had shown beyond reasonable doubt his direct intention to complete an offence against section 194 subsection 1 and the district court's judgement was confirmed.

The means 'other forms of unlawful coercion' were added to the bill of law at the suggestion of the attorney general. The concept can include incidents where difference in age or situation makes the victim unable to resist sexual intercourse. In recent years there has been an increase in sexual offence cases where the perpetrator is accused and found guilty for sexual intercourse which is obtained with other forms of unlawful coercion, not with violence or threats. From the beginning of 2012 to the end of 2017 there were sixteen Supreme Court judgements where a person was accused of an offence against section 194 subsection 1 using unlawful coercion only. The accused was found guilty in nine of these cases. The victims of all these cases were children between eleven and eighteen years old, except in one case where the age was not disclosed. In most of these cases, the accused abused the superior position he had due to difference in age and maturity and took the child to a secluded or unfamiliar place, or somewhere the circumstances made the child feel frightened and helpless. ${ }^{56}$

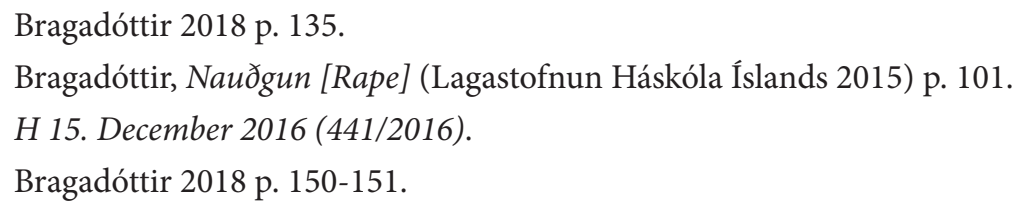


In one case, $\mathrm{X}, 18$ years old, was found guilty of sexual offences against two thirteenyear-old girls. In one instance he used unlawful coercion to force $\mathrm{B}$, who was the friend of X's thirteen-year-old niece, to have oral sex with him. He took B to an apartment where people aged 21-28 were listening to loud music, behaving erratically, drinking alcohol, and taking euphoriant drugs. These were circumstances which would make a thirteen-year-old child feel frightened and helpless. The accused was found guilty according to section 194 subsection 1 and section 202 subsection $1 .{ }^{57}$

In the explanations in the commentary to draft bill to Act no. 61/2007 which defined other sexual relations, there was no mention of a perpetrator forcing a victim to masturbate or a perpetrator forcing two victims to have sexual intercourse. The bill's examples of other sexual relations was not exclusive due to the nature of the concept. There is therefore no reason that the aforementioned actions should not be included in the concept, if applicable. Courts have agreed to this perspective and have interpreted the provision on rape, so that a perpetrator is guilty of rape if he makes victims have sexual intercourse with each other. In a judgement from 2011, for example, the accused was found guilty for an offence against section 194 subsection 2 and section 202 subsection 1 of the GPC, by making his mentally disabled cousins have sexual intercourse and oral sex, with the victims being too afraid to refuse. ${ }^{58}$ The same applies if the accused does not have sexual intercourse with the victim himself, but makes other men, who perform the act believing that the victim has consented, such as in H 12. May 2010 (502/2009) where the accused repeatedly forced his girlfriend, who was living with him, to have sexual intercourse with other men. ${ }^{59}$

The explanations above reveal that with the amendments of the law in 2007, less emphasis was on the means of the offence, but rather whether sexual intercourse had occurred without the victim consenting to it, even though the concept of rape was not defined by the lack of consent in itself. ${ }^{60}$ This emphasis on the lack of consent is evident in Supreme Court cases after 2007, for example in a case from 2017. ${ }^{61}$

In this case, two men had sexual intercourse and other sexual relations with a woman, $\mathrm{P}$, at the same time and together at the home of one of them. Because $\mathrm{P}$ was inebriated she could not resist. P did not know the men at all and did not know where she was. The Supreme Court did not deem it proven that P's situation had been such that section 194 subsection 2 was applicable. However, the Supreme Court agreed with the district court's assessment that it was beyond reasonable doubt that the accused had of having sexual intercourse or other sexual relations with a child under the age of 15 .

58

59

60

61

See H 20. March 2014 (689/2013). Section 202 subsection 1 of the GPC on the criminal liability

H 7. April 2011 (570/2010), see also Bragadóttir 2018 p. 401.

Bragadóttir 2018 pp. 177-179.

Bragadóttir 2018 p. 44.

H 20. June 2017 (486/2016). 
abused P's situation, who 'had no capacity to give her consent because of inebriation,' to obtain sexual intercourse. The big difference in situation and strength between $\mathrm{P}$ and the accused was also taken into account. They were found guilty under section 194 subsection 1 of the GPC. In its decision, the Supreme Court included references to the commentary handed in with bill of law no. 61/2007, where it said that section 194 subsection 1 should be understood so that the essence of a sexual offence is that a person's right to sexual freedom has been violated, and less emphasis is on the means of the offence.

\subsection{Culpability}

Intent is a condition of culpability for rape, and motivation for the actions does not matter. Rape due to negligence has not been discussed as much in Iceland as in the other Nordic countries. However, in the commentary with bill of law no. $61 / 2007$ there was a discussion on whether a provision on rape due to negligence should be taken into force. This discussion referenced the Norwegian provision on rape due to gross negligence and its practice in Norway. ${ }^{62}$ In Norway this provision came into force in $2000 .{ }^{63}$ The majority of the committee on sexual offences had not recommended such a provision, ${ }^{64}$ but the Norwegian Ministry of Justice disagreed. ${ }^{65}$ There are some judgements on grossly negligent rape in Norway, even though they are not many. ${ }^{66}$ The amendments on section 194 in the Icelandic GPC with Act no. $61 / 2007$ made the provision on rape very extensive, as described above. Considering the extensive description of the crime of rape, the idea of adding a provision on negligent rape to Icelandic law, was rejected. In connection with this, it is important that punishment for offences due to negligence in Icelandic law is always much more lenient than for offences committed with intent, and this applies to both the maximum punishment according to the law and the court's sentences. If rape due to negligence were to be implemented in the law, there would be a danger that some offences, which were being punished for as offences of intent, would be considered as offences due to negligence and thereby lessen the victim's legal protection.

62 Alpingistíðindi [Record of Althingi] 2006-2007 pp. 531-533, Bragadóttir 2006 pp. 108-111 and Bragadóttir 2018 pp. 410-422. Section 294 in the Norwegian Criminal Code [Straffeloven 2005-05-20-28]: Grossly negligent sexual assault is punishable by imprisonment for a term not exceeding six years. If circumstances as specified in section 293 (on aggravated sexual assault) exist, the penalty shall be imprisonment for a term not exceeding 10 years.

63 Act 2000-08-11-76.

${ }^{64}$ NOU 1997:23. Norges offentlige utredninger. Sexuallovbrudd [Official Norwegian Report. Sexual Offences].

65 Ot.prp. nr. 28 (1999-2000) Om lov om endringer i straffeloven mv. (seksuallovbrudd) [On Law on Amendments to the Penal Code (Sexual Offences)].

66 See Hennum, Grovt uaktsom voldtekt [Grossly negligent sexual assault]. Bilaga 3, in Leijonhufvud, Samtyckesutredningen - Lagskydd för den sexuella integriteten (Thomson Förlag 2008) pp. 113-119, at 117. 


\subsection{The most extensive provision on rape in the Nordic countries}

It can be argued that with the amendments in 2007, section 194 of the GPC on rape, according to Act no. 61/2007, became the most extensive provision on rape in force in the Nordic countries at the time. ${ }^{67}$ It was more extensive than the Norwegian provision on rape because all instances where the perpetrator exploits the mental illness or disabilities of a victim are defined as rape in Icelandic law, but in Norwegian law only some of these instances are considered to be rape. ${ }^{68}$ The Icelandic provision was more extensive than the contemporary Swedish provision, because according to the Swedish provision, the threats used had to be threats about illegal actions while in the Icelandic provision any threat is applicable if it has the effect that the perpetrator obtains sexual intercourse by means of it. ${ }^{69}$ In Danish law the abuse of the mentally ill or disabled is not defined as rape and is subject to lesser punishment than rape, but in Icelandic law this is also considered to be rape. ${ }^{70}$ There is no doubt that the provision in section 194 of the GPC, according to Act no. $61 / 2007$, and in fact the provisions on rape in all the Nordic countries, are in conformity with the countries' obligations according to international conventions.

67 Bragadóttir, Begrebet voldtægt i et nordisk perspektiv [The concept of rape in a Nordic perspective] NSfK's 58. Research Seminar Report. Nordic Research Council for Criminology (2016) pp. 263-273.

68 According to section 295 in the Norwegian Criminal Code, a penalty of imprisonment for a term not exceeding six years shall be applied to any person who obtains sexual activity for himself/ herself or another person or makes a person perform acts corresponding to sexual activity on himself/herself by exploiting a person's mental illness or mental disability, provided the conduct does not fall within the scope of section 291 on rape.

69 According to the contemporary section 1, chapter 6 in the Swedish Criminal Code (2005), any person who forced another person to have sexual intercourse or other sexual relations by use of violence or a threat of a criminal act was guilty of rape and should be punished with imprisonment from two and up to six years. The Swedish government suggested amendments on the provision on rape based on the lack of consent and these amendments took effect 1 . July 2018. According to the current chapter 6, section 1 on rape in the Swedish Criminal Code, a person can never be considered to be participating voluntarily in sexual intercourse, or in some other sexual act comparable to it, if their participation is a result of assault, other violence or a threat of a criminal act, a threat to bring a prosecution against or report another person for an offence, or a threat to give detrimental information about another person.

70 According to section 218, in the Danish Criminal Code, any person who, by exploitation of another person's mental illness or mental deficiency, procures for himself sexual intercourse with that person shall be liable to imprisonment for any term not exceeding four years. Rape according to section 216 is punished with imprisonment for any term not exceeding eight years. 
Ragnheidur Bragadóttir

\section{A definition of rape based on consent, Act no. 16/2018}

\subsection{Precursor to the amendments}

Even though there has been an extensive provision on rape in Icelandic law since 2007 and the time when violence or threat thereof was required for an offence to count as rape was long gone, the discussion in society on how to define the concept of rape continued, especially among feminists and some Members of the Parliament (MP). However, the Act from 2007 had made an impact, and prosecutors and judges had become much more progressive than before in their approach to these offences. Knowledge about the offences, their characteristics, and consequences has steadily increased and the discussion in society now is quite different from 2007 when the Act no. 61/2007 came into force. An example of this would be the \#metoo-movement, which was at its peak in winter 2018. Women of many different professions, e.g., in politics, media, sports, performance arts, and the criminal justice system, created Facebook groups where they shared their stories. Some men lost their jobs and companies and institutions declared that they would improve.

In autumn 2007 a few MPs put forth a bill for amendments on section 194 subsection 1 of the GPC, in which the definition of rape was to be completely abolished. The proposal for the wording of the provision was as follows: Any person who is guilty of rape is liable to imprisonment for a minimum of 2 years and not exceeding 16 years. $^{71}$ The commentary handed in with the bill said that there were too few convictions and the MPs maintained that the bill had to be enacted to increase their number. The concept of rape would then not need to be defined, because it would be generally known, and the commentary referenced a few concepts that are not defined in the GPC for comparison, for example the concept of theft. ${ }^{72}$

It is difficult to see how the goal of increased convictions could have been obtained with this bill. Its effect could easily have been the complete opposite. If this bill had been enacted it is likely that the older and traditional definition on rape would have been applied in its implementation, a definition which is based on violence and threats thereof. Rape must be defined, and that statement should not require any further argument than to point out that the definition on rape in the Act from 2007 is completely different from its definition in older provisions. The bill that the MPs put forth was undoubtedly well-intended, but unfortunately it was not well-reasoned. It was put forth five more times from 2007 to 2013 but not enacted,

71 Pingskjal [Document of Althingi] 673 - 420. mál, 135. löggjafarping 2007-2008. https://www. althingi.is/altext/pdf/135/s/0673.pdf

Ibid. p. 4. 
as such a vague provision could have caused many problems when implemented. ${ }^{73}$

In 2014 a research report on professionals' views on the handling of rape cases within the criminal justice system was published, along with suggestions on improvements. ${ }^{74}$ The report pointed out the low ratio of indictments in rape cases and that the prosecutors were of the opinion that further amendments to the provision on rape could make it easier to provide evidence of rape. The report therefore stated that further research was needed on whether to change the provision so that 'the essence of the provision would be the lack of consent, instead of violence and threats. ${ }^{75}$ This statement is not completely correct, however, as violence and threats no longer were the essence of the offence of rape and any means used to get sexual intercourse or other sexual relations against the victim's will were considered to be rape.

\subsection{The concept of consent is added to the provision}

During winter 2016-2017 the idea of defining rape based on consent was taken up again when a new draft bill was put forth in the Parliament on amendments to section 194 subsection 1 of the GPC. ${ }^{76}$ This was the initiative of some of Viðreisn's MPs, which was one of the three political parties in Iceland's cabinet at the time. When writing the bill of law, the Swedish report on increased protection on sexual freedom was used as an example, including suggestions on defining rape by lack of consent. ${ }^{77}$ The bill suggested making 'consent the main part in the definition of rape', and that a definition of when there is consent and when not would be included in the provision itself. This suggestion brought consent into the provision and fulfilled the clarity requirement, as it defines when there is and is no consent. This definition applies the same concepts as the law from 2007 , i.e., violence, threats, and other unlawful coercion. ${ }^{78}$

The draft bill on amendments on the provision on rape was put forth in the Parliament

73 See pingskjal [Document of Althingi] 138 - 127. mál, 136. löggjafarping 2008-2009, pingskjal [Document of Althingi] 45 - 45. mál, 138. löggjafarping 2009-2010, pingskjal [Document of Althingi] 49 - 48. mál, 139. löggjafarping 2010-2011, pingskjal [Document of Althingi] 98 - 98. mál, 140. löggjafarping 2011-2012 and pingskjal [Document of Althingi] 372 - 325. mál, 141. löggjafarping 2012-2013.

74 Antonsdóttir: Viðhorf fagaðila til meðferðar nauðgunarmála innan réttarkerfisins og tillögur að úrbótum [Professionals' Views on the Handling of Rape Cases within the Criminal Justice System and Suggestions on Improvements], Edda-öndvegissetur, unnið í samvinnu við innanríkisráðuneytið 2014. This research was supported by Edda Centre of Excellence at the University of Iceland and done in cooperation with the Ministry of the Interior.

$75 \quad$ Ibid. p. 88.

76 Pingskjal [Document of Althingi] 552 - 419. mál, 146. löggjafarping 2016-2017.

77 See SOU 2016:60. The amendments on the chapter on sexual offences in the Swedish Criminal Code [Brottsbalken], which are based on this report, came into force 1. July 2018.

78 Bragadóttir: Hugtakið nauðgun [The Concept of Rape] in Vefrit Úlfljóts (2017) <https://ulfljotur. com/2017/10/01/hugtakid-naudgun/> 
two more times and accepted as Act no. 16/2018. It came into force 13. April 2018 and now the provision on rape reads as follows: ${ }^{79}$

'Section 194 subsection 1: Any person who has sexual intercourse or other sexual relations with a person without his or her consent shall be guilty of rape and shall be imprisoned for a minimum of 1 year and a maximum of 16 years. Consent is considered to have been given if it is freely stated. Consent is not considered to have been given if violence, threats, or other forms of unlawful coercion are employed. 'Violence' here includes deprivation of freedom of action by means of confinement, drugs, or other comparable means.

Section 194 subsection 2: The use of deception, or the exploitation of a person's misconception regarding the situation, or of his or her psychiatric disorder or other mental handicap, or of the fact that, for other reasons, he or she is not in a condition to be able to resist the action or to understand its significance, in order to have sexual intercourse or other sexual relations with him or her, shall also be considered as rape, and shall result in the same punishment as specified in the first paragraph of this Article."80

In addition to the concept of consent being added to the provision on rape in section 194, it was suggested in the bill of law to add to the section the means when a perpetrator uses deception or exploits the victim's misunderstanding of the situation. The bill originally added these means to subsection 1 in the provision and thus it would have been a part of the definition on consent. However, according to the suggestions of the Ministry of Justice's Standing Committee on Criminal Law, these means fit better in section 194 subsection $2,{ }^{81}$ and when the bill was discussed in the Parliament this change was accepted. A provision on the means of deceit or the exploitation of a victim's misunderstanding to have sexual intercourse had been in section 199 of the GPC before the amendments in 2007, when it was abolished, as

79 See pingskjal [Document of Althingi] 10 - 10. mál, 148. löggjafarping 2017-2018 and my review submitted to Althingi's Judicial Affairs and Education Committee, 22. January $2018<\mathrm{http} / /$ www.althingi.is/altext/erindi/148/148-205.pdf>

80 Translation obtained from the Ministry of Justice's website < https://www.government.is/lisalib/ getfile.aspx?itemid=dd8240cc-c8d5-11e9-9449-005056bc530c>

81 Umsögn refsiréttarnefndar til Alpingis [A review of the Ministry of Justice's Standing Committee on Criminal Law submitted to the Althingi], 26. February $2018<$ http://www.althingi.is/altext/ erindi/148/148-367.pdf> 
has been discussed above. ${ }^{82}$ This old provision included incidents where a victim thought he/she was having intercourse with someone other than he/she really was. This was, for example, applicable if the victim was blind or if the incident happened in darkness. This conduct was not defined as rape before the amendments in 2007 and was subject to much more lenient punishment than rape, i.e., imprisonment not exceeding six years. When the chapter on sexual offences was revised with Act no. $61 / 2007$ the provision in the contemporary section 199 of the GPC was abolished. The argument was that this provision was most likely to be applied if the victim of the offence was sleeping, mentally ill or disabled. If this was the victim's condition, it would be a much more serious offence than described in the contemporary section 199 and should be defined as rape, as per section 194. In the commentary with the bill of law from 2007 it was therefore concluded that the provision was no longer relevant, as its contents were moved to the provision on rape ${ }^{83}$ However, the Supreme Court did not agree with this point of view in a judgement from $2010 .{ }^{84}$

In this case, A went to party at Hotel Borg, where she met B, and went with him to his hotel room. They chatted and had sexual intercourse. B then went out, but A fell asleep in bed. Later A became aware that a man came to bed and lay down behind her. They had sexual intercourse and she did not see the man's face until a few minutes later. This man turned out to be a different man from the one she had gone to bed with. This man, X, was accused of having had sexual intercourse with her against her will and had exploited the fact that she was not able to resist the action or to understand its significance as she thought he was a different man. In the indictment the act was said to be mainly an offence against section 194 subsection 2, or section 209 on violation against decency, in case section 194 was not accepted. The district court, and later the SupremeCourt, deemed that these actions were not applicable to section 194 subsection 2's description of the offence, but that section 199 subsection 1 in the abolished law would have been applicable. X was therefore found guilty of violation against decency, according to section 209 of the GPC, which is a much more lenient offence than rape.

As the Supreme Court did not agree to this interpretation of section 194 subsection 2 , it was necessary to include this interpretation clearly in section 194 of the GPC on

82 Träskman, Om straffbar 'tilsnigelse' i ett nordiskt perspektiv [On Criminal Deceit from a Nordic Perspective] in 81 Nordisk Tidsskrift for Kriminalvidenskab (1994) pp. 111-121, at 114. Provisions comparable to this former Icelandic section 199 on deceit or the victim's misunderstanding of the situation were in the Norwegian Criminal Code (section 195) and the Danish Criminal Code (section 221), but abolished in Norway in 1927. It is still in force in the Danish Criminal Code, but was amended in 2013, and is now as follows: 'Any person who has sexual intercourse with any other person who mistakes the perpetrator for someone else shall be liable to imprisonment for any term not exceeding four years.' Such provisions were not in the Swedish or Finish Criminal Codes.

83 Bragadóttir 2006 pp. 105-106.

84 H 20. May 2010 (620/2009). 
rape ${ }^{85}$ This has been accomplished now. ${ }^{86}$

\subsection{Definition of the concept of consent}

In the commentary handed in with the bill of law in 2018, it says that according to the new wording in section 194 subsection 1, the provisions' main emphasis is on whether sexual intercourse is performed with the will and consent of those involved. ${ }^{87}$ The main requirement is that there is no consent to the sexual intercourse. Consent to taking part in the intercourse must be given with words or other unmistakable expression. Therefore, consent must be expressed in some way. Active participation can be interpreted as consent on the part of one or more participants. Complete omission will not be interpreted as willing participation. It is not required that the victim protests or struggles against participation in sexual actions. The consent is only limited to that specific instance and the sexual actions that the consent is given to at each time. A participant in a sexual action can change his/ her mind whenever, but must then express that with words or in another way so that other participants realise it. ${ }^{88}$ These last points are not new, because they were emphasized in 2007. In the commentary with bill of law no. $16 / 2018$, it says that it is not considered practical to define too extensively how consent shall be given. Such a legal definition could be too different from what human relations really are.

When consent has been given, it needs to be revealed if it was given of free will, i.e., that violence, threats or other unlawful coercion was not used. These are the same points that were listed as means in the provision on rape from 2007. The definition of rape based on consent that follows from Act no. 16/2018 does therefore not change much of the contents of the provision on rape.

Finally, in the commentary it says that it is not advisable to change the culpability requirement in the rape offence. Rape should still require that the offender acts intentionally. ${ }^{89}$

$85 \quad$ Bragadóttir 2018 pp. 258-261.

86 Cf. section 194 subsection 2 as amended with Act no. 61/2007.

87 The following discussion on consent is based on the commentary handed in with bill of law no. 16/2018, see pingskjal [Document of Althingi] 10 - 10. mál, 148. löggjafarping 2017-2018 p. 8.

88 In H 19. May 2016 (36/2016) it is stated that the victim had originally consented to sexual intercourse with the accused but quickly changed her mind and wanted to stop. She told the accused and resisted, without him giving this any thought. The accused was therefore found guilty of rape, as per section 194 subsection 1 .

89 Pingskjal [Document of Althingi] 10 - 10. mál, 148. löggjafarping 2017-2018 p. 9. 


\subsection{Effects in implementation}

The new Act has only been applied by the courts for just over two years. ${ }^{90}$ The judgements seem to show that the change of the definition of rape has not changed much in practice. This is because the fundamental change was already made in 2007. Most of the offences were committed when the provision of 2007 was still in force. If penal legislation has changed between the offence being committed and the case being brought up in court, the offence shall be judged according to the more recent statute, when it comes to both the offence and the punishment. However, punishment can never be imposed, unless the act was punishable when it was committed, and the sentence may not be more severe than under the earlier statute, as per section 2 of the GPC (the principle of non-retroactivity). It is therefore clear that in these cases the court is judging in accordance with the new provision. However, the judgements often reference the commentary to the Act from 2007 on the contents of rape and that the essence is that sexual intercourse has taken place without the victim's consent and that the victim's right to self-determination in sex is therefore violated. ${ }^{11}$

The first case that discussed the provision on rape from 2018 was about $\mathrm{X}$ who was accused of being violent towards A and subjugated her to unlawful coercion, after they started having sexual intercourse with the consent of both of them. The judgement states that it is not deemed that the amendments 'on section 194 have an effect in this case, as the incident fits to the description in section 194 like the provision is now, as well as at the time of the incident.' The majority of the High Court found the accused not guilty, as they deemed it not proven that he had the intention to be more violent towards $A$ than she had consented to and it was not proven that he intended to violate her right of self-determination. One judge delivered a minority opinion. There he references commentaries with both Acts, 2007 and 2018, e.g., the wording in the commentary from 2007 that lack of consent is included in the concept of rape, as it is lack of consent that makes the actions rape and therefore punishable. The judge said that $\mathrm{X}$ 'must have known that these violent sexual actions needed the victim's unmistakable consent and that he could not have taken their former sexual intercourse and the victim's consent to sexual intercourse in this case as consent to such violent sexual intercourse.' The judge therefore deemed that X had intention of rape. ${ }^{92}$

By going through the High Court's judgements since the law came into force in 2018 until June 2020, no case considers rape according to the definition from 2018 that would not be considered as rape under the provision from 2007. However, it is not impossible that such cases can come up when the provision has been in effect for a longer period.

$90 \quad$ Act no. 16/2018 came into force 13. April 2018.

$91 \quad$ See L 26. June 2018 (26/2018), L 14. September 2018 (151/2018), L 28. September 2018 (75/2018) and $L$ 1. February 2019 (363/2018).

$92 \quad$ L 28. September 2018 (75/2018). 
Ragnheidur Bragadóttir

\subsection{The effect of the amendments from 2018}

In general discussion, the two definitions on rape, used in the provisions from 2007 and 2018, have often been put forth as two opposites: on one hand to define the offence by listing all possible means, on the other to define the offence as sexual intercourse without consent. However, the difference is in fact very small, if any, and the two definitions essentially have the same meaning. Consent, or lack thereof, is the essence of the offence in both definitions. It is the underlying prerequisite in the definition from 2007, and it is stated clearly in the definition from 2018. Both definitions list the same means, in the provision from 2007 they are means used for the offence, and in the provision from 2018 they are elements in the definition of consent. The content of the provision on rape has therefore not changed in substance by having consent added to it, as the provisions from 2007 and 2018 are made up of the same elements and they differ only in their presentation. It can therefore be concluded that it does not matter which definition is used, and that it is a misunderstanding that a definition based on consent solves the problem of obtaining a guilty verdict in rape cases. The problem has not been solved with this new definition, and recent judgements support this conclusion.

Looking at the discussion above, it can be questioned whether the amendments from 2018 were an improvement. I think they were, to some extent. When studying the commentary to the bill of law no. 16/2018 it can be deduced that the goal of the amendments is threefold. One goal is presumably to obtain more guilty verdicts in rape cases. This has not been the case until now. England's experience shows that low ratio of guilty verdicts is also a problem even though the definition of rape is based on consent. ${ }^{93}$ The commentary says that requirements of proof shall be the same as before, and proof is always difficult in these cases. However, the commentary does say that proof could become easier in some cases. ${ }^{94}$ Another goal is to change the public view of the offence and make it more consistent with people's general understanding and sense of justice than the provision from 2007. I think that is very important, as the law should serve the general public. It is specifically stated in the commentary that the amendments could make young people more aware of the importance of consent. A third goal is the preventive effects that the provision and discussion about it can have, relating also to the aforementioned point about young people and prevention. This is the point that Swedish academics have emphasised..$^{95}$ This is also the point that I consider to be the most important. The goal must be fewer instances of rape and to prevent the damages that rape causes, both for victims and

93 See, for example, Leahy, 'No Means No', But Where's the Force? Addressing the Challenges of Formally Recognising Non-violent Sexual Coercion as a Serious Criminal Offense, The Journal of Criminal Law (2014) pp. 309-325.

94 Pingskjal [Document of Althingi] 10 - 10. mál, 148. löggjafarping 2017-2018, p. 2.

95 Diesen, Tagande med våld - Några reflektioner inför en europeisk våldtäktsstudie. Festskrift till Madeleine Leijonhufvud (Norstedts Juridik 2007) p. 63. See also Leijonhufvud, Svensk sexualbrottslag - En framåtsyftande tillbakablick (Norstedts Juridik 2015) p. 111: 'En samtyckeslag är inte till for att fler ska dömas till fängelse. Den är till för att det ska begås färre övergrepp.' 
perpetrators. However, criminal law is only one link of many in the struggle against sexual violence. Active prevention is essential to the decrease of sexual offences and this is also one of the points the Istanbul Convention addresses. ${ }^{96}$ The main priority for Icelandic society today is therefore to provide funds to strengthen the prevention against sexual offences and to educate the right target groups, preferably young people. This has been done in Sweden, but only to a very little extent in Iceland. ${ }^{97}$

\section{Conclusion}

The enactment of the definition of rape in the Act from 2018 seems to have created a consensus in society on the provision on rape in section 194 GPC by providing victims with sufficient protection. Voices declaring that the provision does not provide enough protection against rape have silenced. In my opinion the explanation is that the current definition of rape in the GPC is an example of the law evolving in accordance with the needs of society and that the definition tries to secure that the law is in accordance with the public's sense of justice. The current provision makes consent more obvious than the provision from 2007 and is easily understood. What we can learn from this is that it is not enough for the law to confirm to the public's will, but this must also be the public's own experience of the situation.

However, the provision from 2007 was so extensive that it can hardly be expected that the provision from 2018 will change much in the courts' handling of rape cases. The experience until now is a confirmation thereof. All the same, the provision in section 194 provides the courts with some space to interpret the concept of consent and it is up to them to try to ensure that the provision has the effect hoped for. Therefore it cannot be said that further amendments on the provision on rape are needed for the time being.

96 Council of Europe Convention on preventing and combating violence against women and domestic violence (2011), Chapter III - Prevention (Article 12-17). 